\title{
Lead, Cadmium and Iron Concentrations in Zea Mays Grown Within the Vicinity of Ori-Ile Battery Waste Dumpsite, Olodo, Ibadan, Nigeria
}

\author{
Adedotun Onoyinka Afolayan 1, 2, *, Amusat Titilayo Hassan² \\ ${ }^{1}$ Tissue Culture/Biotechnology Unit, National Centre for Genetic Resources and Biotechnology, Moor Plantation, Ibadan, Nigeria \\ ${ }^{2}$ Department of Zoology, University of Ibadan, Ibadan, Nigeria
}

Email address:

onoyinka@yahoo.com (A. O. Afolayan),prathassan@yahoo.co.uk (A. T. Hassan)

*Corresponding author

\section{To cite this article:}

Adedotun Onoyinka Afolayan, Amusat Titilayo Hassan. Lead, Cadmium and Iron Concentrations in Zea Mays Grown Within the Vicinity of Ori-Ile Battery Waste Dumpsite, Olodo, Ibadan, Nigeria. American Journal of Bioscience and Bioengineering.

Vol. 5, No. 5, 2017, pp. 92-103. doi: 10.11648/j.bio.20170505.11

Received: August 25, 2017; Accepted: September 8, 2017; Published: November 3, 2017

\begin{abstract}
Agricultural produce resulting from the cultivation of polluted soil can result in undue exposure and health hazards for its consumers at different level along the food chain. Available literature has shown that maize absorbs and accumulates toxic heavy metals from polluted soils. This study was designed to determine the concentration of lead $(\mathrm{Pb})$, cadmium $(\mathrm{Cd})$ and iron $(\mathrm{Fe})$ within the leaf, stem, grains and root of maize grown on Ori-Ile battery waste dumpsite, Olodo, Ibadan Nigeria. Soil samples were collected every two months (March 2008 to July 2009) from the waste dumpsite and along the direction of the garden at $5 \mathrm{~m}$ interval from the edge of the waste dump site. To determine the levels of uptake and accumulation of $\mathrm{Pb}, \mathrm{Cd}$, and $\mathrm{Fe}$, maize was planted in a nearby house garden, situated within $25 \mathrm{~m}$ distance away from the waste dumpsite and the root, stem, leaf and grains were harvested at maturity. All soil samples collected and the harvested maize parts were analysed for $\mathrm{Pb}, \mathrm{Cd}$, and $\mathrm{Fe}$. Concentrations of $\mathrm{Pb}, \mathrm{Cd}$ and $\mathrm{Fe}$ in soil were found to range from 3265.8 \pm 517.8 to $4351.3 \pm 1068.2 ; 163.96 \pm 23.2$ to $258.38 \pm 123.1 ; 7712.90 \pm 473.8$ to $8130.00 \pm 808.4 \mathrm{mg} / \mathrm{kg}$ respectively. These were significantly higher than values obtained from the reference soil $(157.0 \pm 39.8,2.2 \pm 1.2,976.3 \pm 353.9 \mathrm{mg} / \mathrm{kg}$ respectively) and National Environmental Standard Regulation Agency (NESREA) limits $(164 \mathrm{mgPb} / \mathrm{kg}$ and $50 \mathrm{mgCd} / \mathrm{kg}$ ). Also, soil contamination factor values obtained were greater than 6 and this indicated severe contamination. Concentrations of $\mathrm{Pb}, \mathrm{Cd}$ and Fe in maize-parts were significantly higher $(\mathrm{P} \leq 0.05)$ than those cultivated on the reference site soil. Roots had the highest concentration of $\mathrm{Pb}(40.95 \pm 1.98 \mathrm{mg} / \mathrm{L})$ and $\mathrm{Cd}(2.84 \pm 0.19 \mathrm{mg} / \mathrm{L})$. In all maize-parts, bio-accumulation factor of the heavy metals was less than 1. Overall, these results have shown that the levels of metals in soil were several folds above the limits set by NESREA. Also, the range within the analysed plant parts was above the normal limit recommended for plants. High accumulation of heavy metals found in the soils of Ori-Ile battery waste dumpsite, Olodo, Ibadan bio-accumulated in maizeroots. Therefore, maize root is actively involved in phyto extraction of heavy metals from contaminated soils.
\end{abstract}

Keywords: Maize, Lead, Cadmium, Iron, Heavy Metals, Contamination Factor, Bio-Accumulation Factor, Ori-Ile Olodo Waste Dumpsite

\section{Introduction}

Land contamination and degradation is a threat to sustainable agricultural development and food security in developing countries [1]. Uncontrolled open dumping on the peripheries of many cities has resulted in the degradation of valuable land resources and the creation of long-term environmental and human health problems [2]. Numerous industrial activities, including automobile battery production have often resulted in the accumulation of noxious metals in the environment $[3,4,5,6,7]$ and the discharge of heavy metals as a by-product of these activities has been 
accompanied by large scale soil pollution [7, 8]. Heavy metals tend to persist in the environment indefinitely [9] and get accumulated over time in soils and plants. Hence, they could have a negative influence on physiological activities of plants, determining the reductions in plant growth, dry matter accumulation and yield [10]. Excessive accumulation of heavy metals in agricultural soils often lead to elevated heavy metal uptake by crops, and thus affect food quality and safety [11]. Food chain contamination is one of the important pathways for the entry of toxic pollutants into the human body [12] and the consumption of heavy metal-contaminated food can seriously deplete some essential nutrients in the body that are further responsible for decreasing immunological defences, intrauterine growth retardation, impaired psycho-social faculties, disabilities associated with malnutrition and high prevalence of upper gastrointestinal cancer rates $[13,14]$. Heavy metal accumulation in plants depends upon plant species, and the efficiency of different plants in absorbing metals is evaluated by either plant uptake or soil-to-plant transfer factors of the metals [15]. Some of the heavy metals such as $\mathrm{Pb}$ and $\mathrm{Cd}$ are toxic to plants and animals, even in trace concentrations [16]; and exposure to some of them is normally chronic due to food chain transfer [17]. $\mathrm{Pb}$ and $\mathrm{Cd}$ have been found to inhibit plant growth, disturb ion uptake and transport as well as inhibit enzyme activation and photosynthesis [18, 19]. Fe is essential for many plant functions [20] but is toxic when it accumulates to high levels. Excess Fe can result in dark green foliage, stunted growth of tops and roots, dark brown to purple leaves on some plants [20].

Ori-Ile, Ikumapaiyi area of Olodo, Ibadan, Nigeria is one of the several areas used as open dump by the waste contractors of the now closed down lead acid battery manufacturing company, known as West African Battery Industry. The allocation of these previously used open waste dumps for housing development has presented series of environmental challenges to the inhabitants [21]. Ori-Ile Olodo residents predominantly grow maize for both human and animal consumption while some of them utilize their harvested maize seeds for constituting feed for their domestic animals [22]. Maize is an important staple crop in Nigeria [23]. It is one of the staple foods consumed by the population of Nigeria in large amount [24]. Maize ranks third in the world production of cereal following wheat and rice [25]. It is used as feed for livestock and a principal raw material for many industrial products $[24,25]$. Maize classified as Zea Mays, is the common name for the cereal grass in the Poaceae, which are known to be good accumulators of contaminants [26]. The uptake, metabolism and negative effects of heavy metals on different plants including maize have been documented in literature [27, 28]. However, the mechanism of accumulation of those heavy metals is still not completely understood [27] especially since $\mathrm{Pb}$ and $\mathrm{Cd}$ are the most widespread no nutrient heavy metals [29]. While the study conducted by Olusoga and Osibanjo [30] at Olodo ibadan touched on concentration of lead and cadmium, on the whole maize plants, the present study is designed to determine the concentration of $\mathrm{Pb}, \mathrm{Cd}$ and $\mathrm{Fe}$ in different parts of cultivated maize plant, namely, the roots, stem, leaves and maize-grains and in soils within the vicinity of Ori-Ile Olodo.

\section{Materials and Methods}

\subsection{Study Area}

The study area is a semi-urban residential and agricultural area located on latitudes $7^{\circ} 24^{\prime} 28.1^{\prime \prime} \mathrm{N}$, longitudes $4^{\circ} 00^{\prime} 52.2^{\prime \prime} \mathrm{E}$ and elevation $176 \mathrm{~m}$ respectively. It contained a waste dumpsite located at Omilende village in Ikumapaiyi Area of Olodo community, northwest of Egbeda Local Government Area, Ibadan, Oyo-State. It is popularly referred to as Ori-Ile Waste Dumpsite. Figure 1 and 2 shows the map of Ibadan with the location of the study site and the map of the study area (Olodo). The study site is a large and bare expanse of land of about 2 hectares, characterized with scanty vegetation. The most abundant group of vegetation on and around the waste dumpsite were the grasses, some of which included Panicum clandestinum (corn grass), Muhlenbergia emersleyi (bull grass) and Echinopogon ovatus (hedgehog grass). Panicum clandestinum were most abundant in areas surrounding the study site. The area has a bimodal rainfall pattern which peaks in June and September. The site was used as an unapproved waste dumpsite for battery wastes from the now closed down company called West African Battery Industry, who used to produce the battery known as 'Exide Battery'. It was also used as an informal lead recovery site by informal and local Used Lead Acid Battery operators.

The area surrounding the waste dumpsite is inhabited by people who are mostly peasant farmers and traders. Some of the residents have gardens in their yard. Among the plants found in these gardens were Zea Mays (Maize), Carica papaya (Pawpaw), Lycopersicon esculentum (Cocoyam), Discorea $s p$ (Yam) etc. Domestic animals are raised by residents living around the study area. Some of them are Gallus gallus domesticus (both local and broiler chicken) and Capra aegagrus hircus (Nigerian Dwarf Dairy Goat). The reference site was located at National Center for Genetic Resources and Biotechnology, Moor Plantation, Ibadan, latitude $7^{\circ} 23^{\prime} 31.5^{\prime}, \mathrm{N}$ and longitude $3^{\circ} 50^{\prime} 46.5^{\prime}{ }^{\prime} \mathrm{E}$. 
MAP OF IBADAN SHOWING SAMPLING POINTS

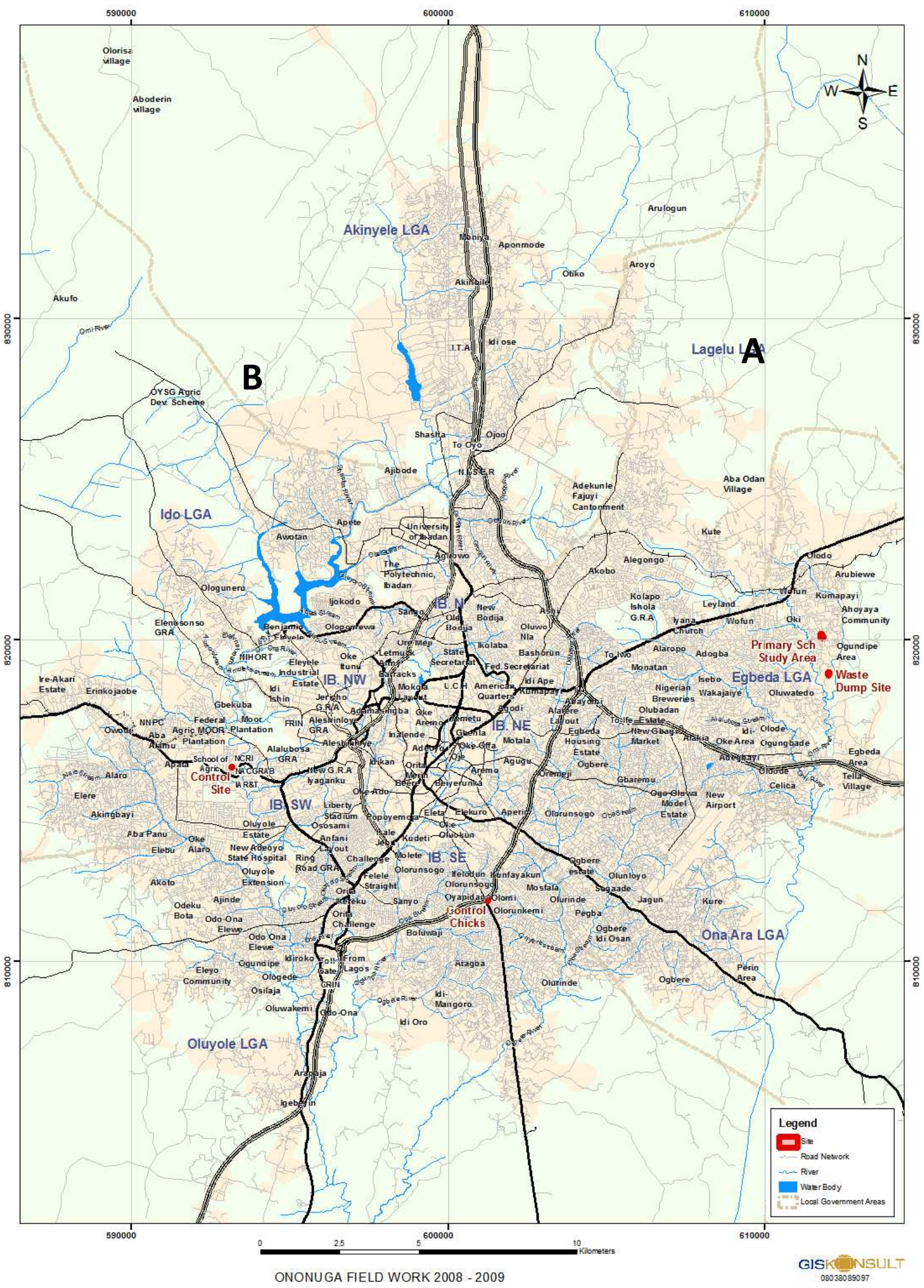

Figure 1. Map of Ibadan showing the Ori-Ile waste dumpsite (A) and reference site (B). (Source: GIS Konsult, Bodija, Ibadan). 


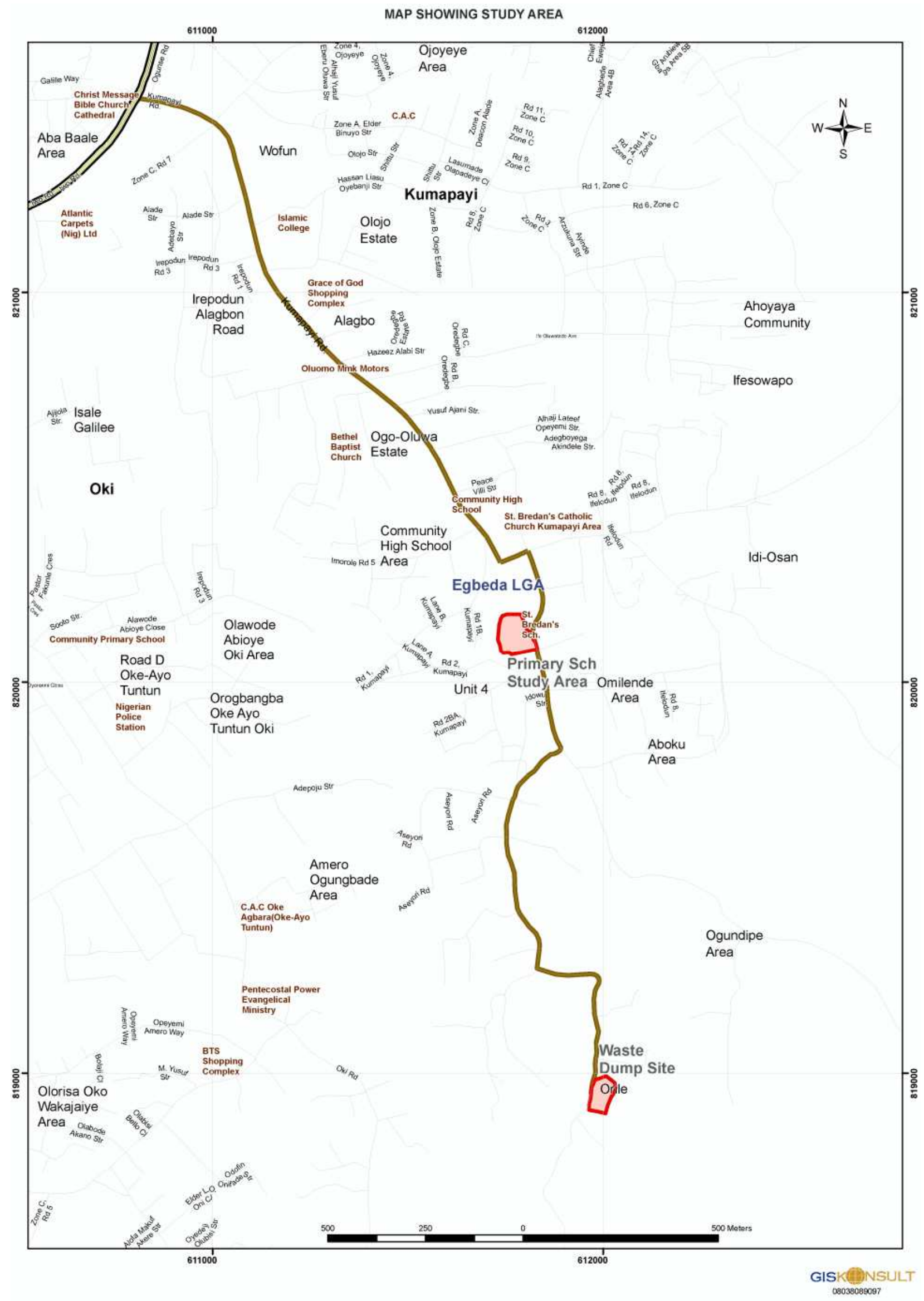

Figure 2. Map of Olodo showing the Ori-Ile waste dumpsite (Source: GIS Konsult, Bodija, Ibadan). 
Table 1. GPS data of the soil sampling points of waste dumpsite and reference site.

\begin{tabular}{|c|c|c|c|c|c|c|}
\hline \multirow{2}{*}{ Sampling Area } & \multirow{2}{*}{$\begin{array}{l}\text { Sampling } \\
\text { distance }\end{array}$} & \multirow{2}{*}{ No of samples per visit } & \multirow{2}{*}{$\begin{array}{l}\text { Sampling } \\
\text { points }\end{array}$} & \multicolumn{3}{|c|}{ GPS Coordinates } \\
\hline & & & & Elevation (m) & NORTH & EAST \\
\hline \multirow{12}{*}{$\begin{array}{l}\text { Experimental } \\
\text { Direction (E) }\end{array}$} & \multirow{3}{*}{$0 \mathrm{~m}$} & \multirow{3}{*}{ One composite sample (E0) } & $\mathrm{AE} 0$ & 174 & $0724^{\prime} 29.3^{\prime \prime}$ & $00400^{\prime} 52.6 "$ \\
\hline & & & ME 0 & 172 & $0724^{\prime} 29.4^{\prime \prime}$ & $00400^{\prime} 53.5^{\prime \prime}$ \\
\hline & & & BE 0 & 171 & $0724^{\prime} 29.2^{\prime \prime}$ & $00400^{\prime} 54.4 "$ \\
\hline & \multirow{3}{*}{$10 \mathrm{~m}$} & \multirow{3}{*}{ One composite sample (E10) } & $\mathrm{AE} 10$ & 174 & $0724^{\prime} 29.7^{\prime \prime}$ & $00400^{\prime} 52.6 "$ \\
\hline & & & ME 10 & 171 & $0724^{\prime} 29.6^{\prime \prime}$ & $00400^{\prime} 53.6 "$ \\
\hline & & & BE 10 & 172 & $0724^{\prime} 29.5^{\prime \prime}$ & $00400^{\prime} 54.5^{\prime \prime}$ \\
\hline & \multirow{3}{*}{$20 \mathrm{~m}$} & \multirow{3}{*}{ One composite sample (E20) } & AE 20 & 171 & $0724^{\prime} 30.0^{\prime \prime}$ & $00400^{\prime} 52.6 "$ \\
\hline & & & ME 20 & 166 & $0724^{\prime} 29.9^{\prime \prime}$ & $00400^{\prime} 53.8 "$ \\
\hline & & & BE 20 & 170 & $0724^{\prime} 29.7 "$ & $00400^{\prime} 54.4 "$ \\
\hline & \multirow{3}{*}{$25 \mathrm{~m}$} & \multirow{3}{*}{ One composite sample (E25) } & AE 25 & 172 & $0724^{\prime} 30.2^{\prime \prime}$ & $00400^{\prime} 52.8 "$ \\
\hline & & & ME 25 & 170 & $0724^{\prime} 30.1^{\prime \prime}$ & $00400^{\prime} 53.8^{\prime \prime}$ \\
\hline & & & BE 25 & 169 & $0724^{\prime} 29.9^{\prime \prime}$ & $00400^{\prime} 54.5^{\prime \prime}$ \\
\hline \multirow{4}{*}{ Waste dumpsite sample } & \multirow{4}{*}{ Random } & \multirow{4}{*}{ One composite sample $(\mathrm{Rd})$} & $\operatorname{Rd} 1$ & 173 & $0724^{\prime} 28.6^{\prime \prime}$ & $00400^{\prime} 53.0^{\prime \prime}$ \\
\hline & & & $\operatorname{Rd} 2$ & 174 & $0724^{\prime} 28.5^{\prime \prime}$ & $00400^{\prime} 53.8 "$ \\
\hline & & & $\mathrm{Rd} 3$ & 175 & $0724^{\prime} 26.8^{\prime \prime}$ & $00400^{\prime} 53.3^{\prime \prime}$ \\
\hline & & & $\operatorname{Rd} 4$ & 175 & $0724^{\prime} 27.1^{\prime \prime}$ & $00400^{\prime} 52.6 "$ \\
\hline Reference Site (C) & Random & One composite sample & $\mathrm{C}$ & & $0723^{\prime} 31.5^{\prime \prime}$ & $00350^{\prime} 46.5^{\prime \prime}$ \\
\hline
\end{tabular}

\subsection{Sampling Procedure and Analysis}

\subsubsection{Soil}

Forty (40) top soil samples were obtained from the study site in 2008 (March, May, July and September) and 2009 (January, March, May, and July). Samples were not obtained in November 2008 due to health constraints. The guidelines provided by USEPA [32] were employed during sampling. The soil samples were taken at the top region only $(0-15 \mathrm{~cm}$ deep); along a straight line $\mathrm{A}$ to $\mathrm{B}$ with a midpoint $\mathrm{M}$ and bulked together to form a composite sample. Geographical Positioning System (GPS) was employed in acquiring location information on specific points of sample collection during each visit (Table 1).

The soil samples were collected from the waste dumpsite and along the direction of the experimental garden at $5 \mathrm{~m}$ intervals from the edge of the wastedump site with the aid of a soil auger and hand trowel into clean, well-labelled polythene sampling bags. The sampling bags were sealed to prevent contamination during transportation to the laboratory and were then taken to the laboratory for processing and analysis. The digestion of the samples was done according to the method adopted by Adie and Osibanjo [33]. The filtrate of the digested samples was made up to the final volume $(100 \mathrm{ml})$ and analysed for $\mathrm{Pb}, \mathrm{Cd}$ and $\mathrm{Fe}$ with Perkin Elmer Analyst 200 Atomic Absorption Spectrophotometer (2003 Model). The procedure was repeated for all the samples and their replicates. Reference soils were also collected and subjected to the same procedural analysis.

The $\mathrm{pH}$ of the soil samples was determined with the aid of a calibrated Jenway glass electrode $\mathrm{pH}$ meter according to the procedure of ASTM [63].

\subsubsection{Maize}

To determine the levels of uptake and accumulation of $\mathrm{Pb}$, $\mathrm{Cd}$, and $\mathrm{Fe}$ in plants, maize was planted in a nearby house garden tagged 'experimental garden'. The garden was situated within $25 \mathrm{~m}$ distance away from the waste dumpsite. At maturity, the root, stem, leaf and grains were harvested. Reference maize plants were also cultivated and the parts were also harvested at maturity. Each harvested maize parts were kept in well-labelled polythene bags and taken to the laboratory for further analysis. At the laboratory, each harvested maize parts were washed with deionised water to remove any debris prior to drying. Representative amounts of the plant tissues were oven-dried at $65^{\circ} \mathrm{C}$ to constant weights and ground in a porcelain mortar. Between $0.02 \mathrm{~g}$ and $1 \mathrm{~g}$ of the ground samples were weighed into vitreosil crucibles and dry-ash in a muffle furnace at $450-500^{\circ} \mathrm{C}$ for $3 \mathrm{hrs}$. The ash was dissolved with $5 \mathrm{ml}$ of hot $6 \mathrm{M}$ nitric acid $\left(\mathrm{HNO}_{3}\right)$ and evaporated on a hotplate. After evaporation, $1 \mathrm{ml}$ of $6 \mathrm{M}$ nitric acid was added followed by deionised water and then the sample solution was filtered. The filtered extract was made up to $25 \mathrm{ml}$ with deionised water in a volumetric flask and then stored in acid-washed plastic vials with screw caps prior to analysis [34]. Extracts of the plant samples were then analysed for lead, cadmium, and iron using flame atomic absorption spectrophotometer (Buck 200A).

\subsubsection{Quality Control}

Quality control of metal analysis was performed by analysing reference samples of both plants and soil, and for reagents the quality assurance scheme included blank reagents.

\subsubsection{Calculated Factors}

Contamination and transfer Factors (CF, TF) were 
determined for soil and maize respectively using the methods adopted by Agunbiade and Fawale [35] and Cui et al [36].

1. Contamination Factor (CF) is often used to access soil contamination through the comparison of the concentrations in the surface layer to the background values. It is calculated using the equation:

$$
\mathrm{CF}=\mathrm{C}_{(0-1)} / \mathrm{C}_{\mathrm{n}}
$$

(Where $\mathrm{CF}=$ contamination factor; $\mathrm{C}_{(0-1)}=$ mean of concentrations of individual metal from all test sites; $C_{n}=$ baseline or background concentration of individual = concentration of metals at control site).

$\mathrm{CF}<1=$ low contamination factor

$1<\mathrm{CF}<3=$ moderate contamination factor

$3<\mathrm{CF}<6=$ considerable contamination factor

$\mathrm{CF}>6=$ very high contamination factor

Transfer Factor (TF): This is the concentration of each of the metal in the maize relative to the level of the metal in the corresponding soil on dry weight basis, respectively.

$$
\mathrm{TF}=\mathrm{C}_{\mathrm{p}} / \mathrm{C}_{\mathrm{s}}
$$

(Where $\mathrm{C}_{\mathrm{p}}=$ concentration of the metal in the plant (maize) while $\mathrm{C}_{\mathrm{s}}=$ concentration of the metal in the corresponding soil) [36].

$\mathrm{TF}>1=$ High level of accumulation of metal in the plant

2. Pollution Load Index (PLI): is used to evaluate the severity of pollution of the soils and plants according to the definition of Tomlinson et al. (1980). It is calculated using the equation:

$$
\text { PLI }=\left[\pi^{\mathrm{n}} \mathrm{i}\left(\mathrm{c}_{\mathrm{fi}}\right)\right]^{1 / \mathrm{n}}
$$

(Where, Cfi is the concentration factor of each metal obtained by the ratio of concentration of each metal in soil or plant to that of the metal in baseline soil or plant; $\pi$ is the geometrical mean operator; $\mathrm{n}$ is the number of metals investigated and $i$ is each metal).

When PLI value is below or close to one, it indicates heavy metal loads at the baseline, while values above one indicate heavy metal accumulation or pollution in plant or soil from the test site.

\subsection{Statistical Analysis}

Table 2. Mean Concentrations of $\mathrm{Pb}, \mathrm{Cd}$ and $\mathrm{Fe}(\mathrm{mg} / \mathrm{kg})$ in Soils of Waste Dumpsite (Rd) and along Experimental Garden Direction (E).

\begin{tabular}{llll}
\hline Sampling Point and Distance & $\mathbf{P b}(\mathbf{m g} / \mathbf{k g})$ & $\mathbf{C d}(\mathbf{m g} / \mathbf{k g})$ & $\mathbf{F e}(\mathbf{m g} / \mathbf{k g})$ \\
\hline Rd & $4273.8 \pm 1436.7$ & $258.38 \pm 123.1$ & $7910.00 \pm 791.5$ \\
E0 & $4351.3 \pm 1068.2$ & $248.21 \pm 92.7$ & $8130.00 \pm 808.4$ \\
E10 & $4186.7 \pm 762.0$ & $224.29 \pm 60.8$ & $7805.41 \pm 808.7$ \\
E20 & $3775.8 \pm 527.8$ & $193.62 \pm 40.4$ & $7769.59 \pm 398.4$ \\
E25 & $3265.8 \pm 517.8$ & $163.96 \pm 23.2$ & $7712.90 \pm 473.8$ \\
C & $157.0 \pm 39.8$ & $2.21 \pm 1.2$ & $976.3 \pm 353.9$ \\
NESREA & 164 & 50 & N. A. \\
\hline
\end{tabular}

Each value is expressed as Mean \pm Standard Deviation (SD)

$\mathrm{Rd}=$ Waste dumpsite soil sample; $\mathrm{E}=$ Experimental garden soil sample; $\mathrm{C}=$ Reference site soil sample; N. A. = Not Available
The results of all the heavy metals in the soil samples were grouped and analysed using factorial tool to compress the data and identify patterns of relationship within them. The results of the heavy metals in the maize parts were analysed for level of significance using the Student's T-test with a significance level of $\mathrm{p} \leq 0.05$.

\section{Results and Discussion}

\subsection{Pb, Cd and Fe Concentrations in Soil Samples}

In the topsoil samples collected from the waste dumpsite (Rd sample) and the distances sampled along the Experimental Garden Direction from the edge of the waste dumpsite (E), a wide range of soil $\mathrm{Pb}, \mathrm{Cd}$ and $\mathrm{Fe}$ concentrations were observed (Table 2; Figure 3, 4, and 5). In $\mathrm{Rd}$ and $\mathrm{E}$ soils, $\mathrm{Pb}, \mathrm{Cd}$, and $\mathrm{Fe}$ concentrations were significantly higher $(p \leq 0.05)$ compared with the reference soils $(\mathrm{C})$. The results indicated that $\mathrm{Pb}$ and $\mathrm{Cd}$ concentrations exceeded the Environmental Quality Standards set by NESREA for soils in Nigeria (Table 2). However, there was significant accumulation of $\mathrm{Pb}, \mathrm{Cd}$, and $\mathrm{Fe}$ in the waste dumpsite soils and those towards the Experimental Garden Direction compared to the reference soils. The CF and PLI indices respectively, using the reference soil concentrations of this study were significantly very high. For the waste dumpsite (Rd), the $\mathrm{CF}$ for $\mathrm{Pb}$ was 27.22 while the PLI was 9.45; for $\mathrm{Cd}$, the $\mathrm{CF}$ was 117.27 while the PLI was 15.38 ; and for $\mathrm{Fe}$, the CF was 8.10 while the PLI was 6.31. For distances $0 \mathrm{~m}$ to $25 \mathrm{~m}$ along the experimental garden direction (E) from the edge of the waste dumpsite (E), the CF for $\mathrm{Pb}$ was 24.81 while the PLI was 9.16; for $\mathrm{Cd}$, the $\mathrm{CF}$ was 94.32 while the PLI was 14.31; and for Fe, the CF was 8.05 while the PLI was 6.30 . Overall, Rd topsoil had the highest contamination factor (CF) and this was significantly higher than six (6), which was the recommended value. This thus shows that there is severe contamination of the topsoil sampled on waste dumpsite and distances $0 \mathrm{~m}$ to $25 \mathrm{~m}$ along the experimental garden direction (E) from the edge of the waste dumpsite. All the soil PLI values were above one (1) and this further indicated significant heavy metal accumulation and pollution in soil from the study site. 


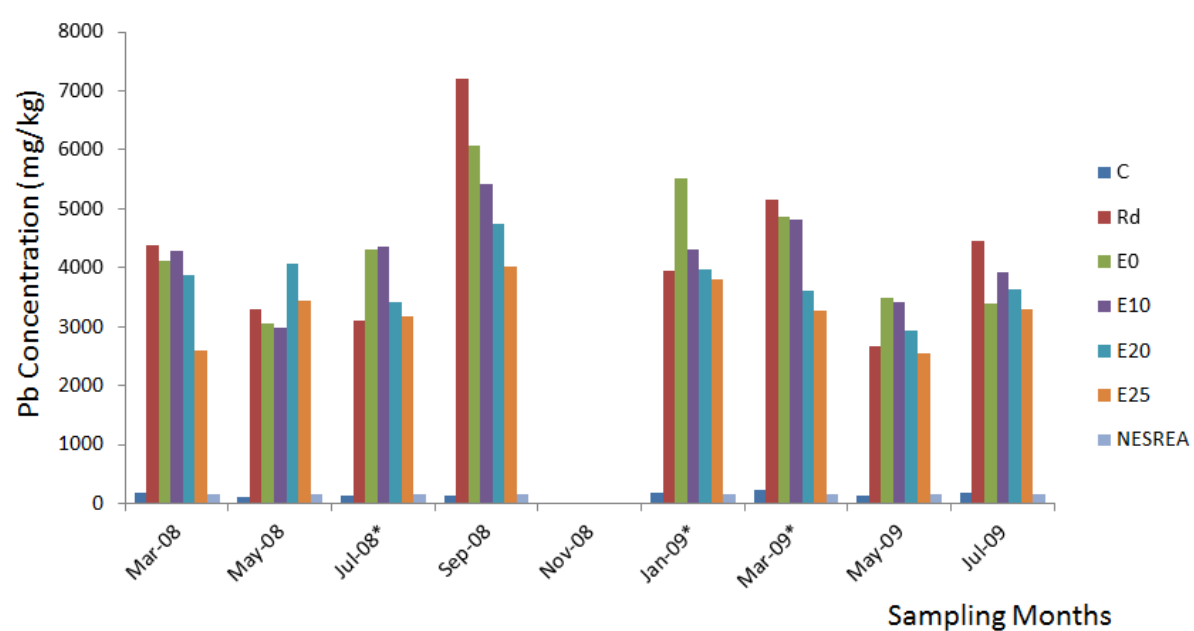

Figure 3. Bimonthly Concentration of Lead in Soils of Waste Dumpsite (Rd) and along Experimental Garden Direction.

Key: * = significant. Each bar = sampling months; successive colors = collection points' lead content $(\mathrm{C}=$ reference soil, $\mathrm{Rd}=$ waste dumpsite soil, $\mathrm{E}=$ Experimental Garden Direction Soil).

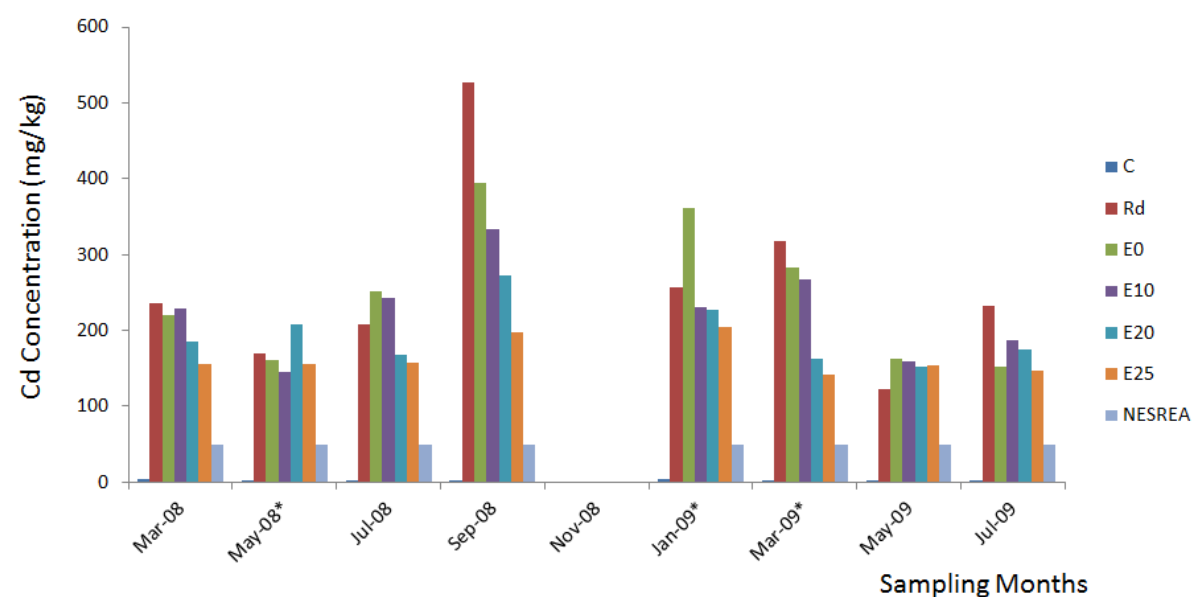

Figure 4. Bimonthly Concentration of Cadmium in Soils of Waste Dumpsite (Rd) and along Experimental Garden Direction.

Key: ${ }^{*}=$ significant. Each bar = sampling months; successive colors = collection points' Cadmium content $(\mathrm{C}=$ reference soil, $\mathrm{Rd}=$ waste dumpsite soil, $\mathrm{E}=$ Experimental Garden Direction Soil).

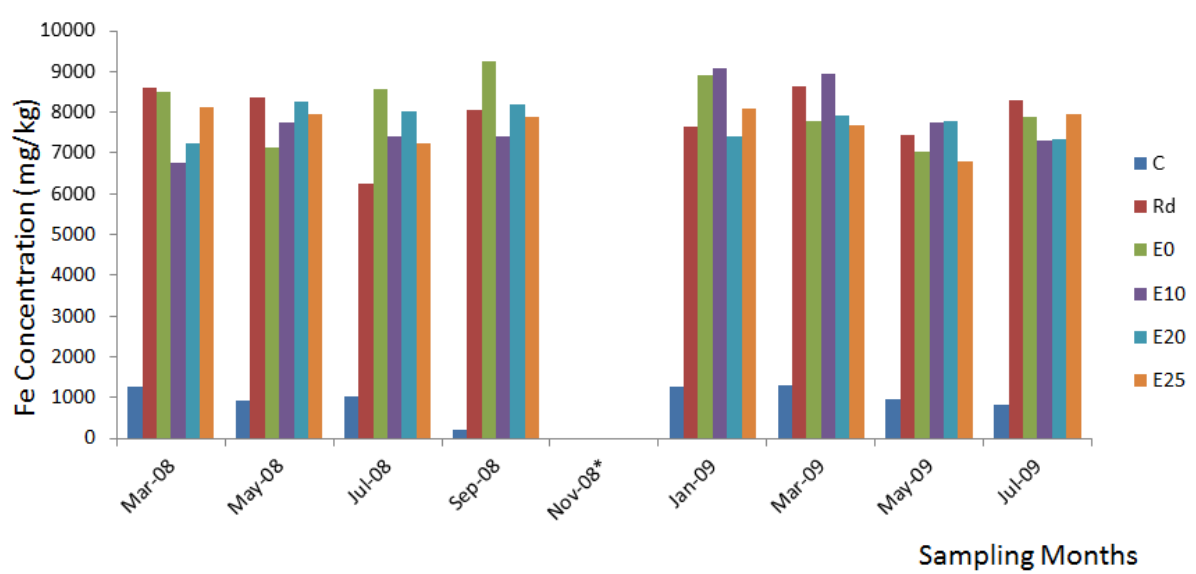

Figure 5. Bimonthly Concentration of Iron in Soils of Waste Dumpsite (Rd) and along Experimental Garden Direction.

Key: ${ }^{*}=$ significant. Each bar $=$ sampling months; successive colors $=$ collection points' iron content $(\mathrm{C}=$ reference soil, $\mathrm{Rd}=$ waste dumpsite soil, $\mathrm{E}=$ Experimental Garden Direction Soil). 
This study has revealed that $\mathrm{Pb}, \mathrm{Cd}$ and $\mathrm{Fe}$ concentrations in the topsoil of the waste dumpsite (Rd) and those of distances $0 \mathrm{~m}$ to $25 \mathrm{~m}$ along the experimental garden direction (E) from the edge of the waste dumpsite were significantly higher than the values obtained from the reference site topsoil. Also, $\mathrm{Pb}, \mathrm{Cd}$ and $\mathrm{Fe}$ concentration in the Rd topsoil was significantly higher than those in the distance towards $\mathrm{E}$ and decreased with increased distance away from $\mathrm{Rd}$. $\mathrm{Pb}$ and $\mathrm{Cd}$ concentrations obtained were several folds higher than the maximum permissible limit of $164 \mathrm{mg} / \mathrm{kg}$ and $50 \mathrm{mg} / \mathrm{kg}$ by NESREA [37].

According to Chirenje et al. [38] and Oni [2], Pb occurs naturally in all soils in concentrations ranging from 1 to 200 $\mathrm{mg} / \mathrm{kg}$ with a mean of $15 \mathrm{mg} / \mathrm{kg}$ but the values obtained in this study for Rd topsoil and those of distances $0 \mathrm{~m}$ to $25 \mathrm{~m}$ along $\mathrm{E}$ direction from the edge of the waste dumpsite were several times beyond this range. WHO [39] reported that normal concentrations of $\mathrm{Pb}$ in soil to range from 15 to 30 $\mathrm{mg} / \mathrm{kg}$ but this study $\mathrm{Pb}$ values were much higher than this value. $\mathrm{Pb}$ concentrations obtained were at very high concentrations than the maximum tolerable levels proposed for agricultural soils, $90-300 \mathrm{mg} \mathrm{kg}-1[40,41]$. This shows a very high level of $\mathrm{Pb}$ contamination of the topsoil of the study site. Onianwa and Fakayode [42], in their study on lead contamination of topsoil in the vicinity of a battery factory in Nigeria, reported the mean lead level of $50-2000 \mathrm{mg} / \mathrm{kg}$ in the topsoil studied. However, this study $\mathrm{Pb}$ values exceeded this range reported. In the study of Adie and Osibanjo's [33] on soil polluted by slag from an automobile battery manufacturing plant in Nigeria, a range of 243 $126000 \mathrm{mg} / \mathrm{kg}$ was reported for $\mathrm{Pb}$ concentration. The mean values obtained in all the samples on and within the vicinity of the dumpsite were within this range and thus compare significantly with the result reported. The range of 419.54 $10630.04 \mathrm{mg} / \mathrm{kg}$ was reported in the studies conducted by Oyediran and Aladejana [21] on impact assessment and safety status of the excavated waste site at Olodo, Ibadan, Nigeria. This also corroborates the values obtained in this study.

WHO [43] reported that the median Cd concentration in soil of areas not known to be polluted ranges from $0.2-0.4$ $\mathrm{mg} / \mathrm{kg}$. The cadmium concentrations obtained in this study were far higher than these stated values. The range of 1.95 $32.83 \mathrm{mg} / \mathrm{kg}$ obtained by Oyediran and Aladejana [21] in their studies on battery waste polluted areas was much less than the values obtained for $\mathrm{Cd}$ concentration in this study.

According to Eddy et al [44], the background level of Fe in natural soils was stated to range widely between 3,000 $500,000 \mathrm{mg} / \mathrm{kg}$ on elemental composition of soil in some dumpsites in Nigeria. The values obtained for soil iron concentrations in this study falls within the range reported by Eddy et al [44] as the background level of iron in natural soils. Oyediran and Aladejana [21] reported the range of $32900.08 \mathrm{mg} / \mathrm{kg}-71250.17 \mathrm{mg} / \mathrm{kg}$ for Fe concentrations in their studies on battery waste polluted areas. The $\mathrm{Fe}$ concentrations obtained in this study were several folds lower than those reported.

All soil contamination factors $(\mathrm{CF}>6)$ and pollution load indices (PLI $>1$ ) were significantly high. This confirmed high pollution of the waste dumpsite and its surrounding along the direction of the experimental garden. From the contamination factor and pollution load index values obtained, $\mathrm{Cd}$ was the highest contaminant in all the top-soils sampled at the study site, followed by $\mathrm{Pb}$ and $\mathrm{Fe}$. The $\mathrm{CF}$ and PLI values for samples collected from the waste dumpsite for $\mathrm{Pb}, \mathrm{Cd}$ and $\mathrm{Fe}$ indicated that the topsoil on the waste dumpsite had the highest pollution for $\mathrm{Pb}, \mathrm{Cd}$ and $\mathrm{Fe}$, followed by the topsoil along the experimental garden directions in that order.

The $\mathrm{pH}$ of topsoil of the waste dumpsite ranged from 4.00 in May 2008 to 5.76 in September 2008 with a mean \pm standard deviation of $5.20 \pm 0.66$ while the $\mathrm{pH}$ of topsoil of the distances $0 \mathrm{~m}$ to $25 \mathrm{~m}$ along the experimental garden direction (E) from the edge of the waste dumpsite ranged from 4.62 in March 2009 to 6.60 in May 2009 with a mean \pm standard deviation of $5.35 \pm 0.66$. The topsoil of the reference site had a pH that ranged from 6.02 in May 2008 to 6.75 in January 2009 with a mean and standard deviation of $6.58 \pm 0.22$. There were no significant differences $(p=0.05)$ between the $\mathrm{pH}$ of the waste dumpsite and those of distances $0 \mathrm{~m}$ to $25 \mathrm{~m}$ along the experimental garden direction (E) from the edge of the waste dumpsite; but these were significant different from the $\mathrm{pH}$ of the reference site. The $\mathrm{pH}$ results obtained in this study may be as a result of the acidic components of the battery production, which were contained in the waste. Hence, when the battery wastes were disposed on the soils, they modified the soil's $\mathrm{pH}$, causing it to be more acidic. This can affect the uptake and bioaccumulation of the toxic components of the battery wastes. The uptake of cadmium by plants from soil is also greater at low soil $\mathrm{pH}$ [43]. The $\mathrm{pH}$ of the topsoil of the study site being acidic fit into the above statement and could enhance the uptake of lead and cadmium into plants growing on the polluted dumpsite environment.

\subsection{Pb, Cd and Fe Concentrations in Maize Parts}

The concentrations of $\mathrm{Pb}, \mathrm{Cd}$ and $\mathrm{Fe}$ measured in the different parts of the cultivated maize namely roots, stems, leaves and grains were compared to values obtained from reference site maize.

$\mathrm{Pb}$ concentrations: The result obtained showed a significant difference among the mean $\mathrm{Pb}$ concentration of the different maize parts and student's T-test results showed that the differences in mean values for the different maize parts were significant at $p \leq 0.05$. The cultivated maize root had the highest $\mathrm{Pb}$ concentration than the other maize parts.

Cd Concentrations: The result obtained showed a significant difference among the mean Cd concentration of the different maize parts. The student's T-test results showed that the differences in mean values for the different maize parts were significant at $\mathrm{p} \leq 0.05$. The cultivated maize root had the highest $\mathrm{Cd}$ concentration than the other maize parts.

Fe Concentrations: The result obtained showed a 
significant difference among the mean Fe concentration of the different maize parts. The student's T-test results showed that the differences in mean values for the different maize parts were significant at $\mathrm{p} \leq 0.05$. The cultivated maize leaf had the highest Fe concentration than the other maize parts.

Table 3. Transfer Factors and Pollution Load Indices (PLI) for Lead, Cadmium and Iron in the Cultivated Maize Parts.

\begin{tabular}{|c|c|c|c|c|}
\hline Calculated Indices & Maize Parts & $\mathbf{P b}$ & Cd & $\mathbf{F e}$ \\
\hline \multirow{3}{*}{ Transfer factor (TF) } & TF maize grains & 0.0096 & 0.1803 & 0.0048 \\
\hline & TF maize stem & 0.0094 & 0.1755 & 0.0046 \\
\hline & TF maize root & 0.0105 & 0.1973 & 0.0052 \\
\hline \multirow{3}{*}{ Pollution Load Index (PLI) } & PLI maize grains & 0.668 & 1.766 & 0.530 \\
\hline & PLI maize stem & 0.663 & 1.760 & 0.523 \\
\hline & PLI maize root & 0.688 & 1.830 & 0.545 \\
\hline
\end{tabular}

TF/PLI $<1=$ low; TF/PLI $>1=$ high

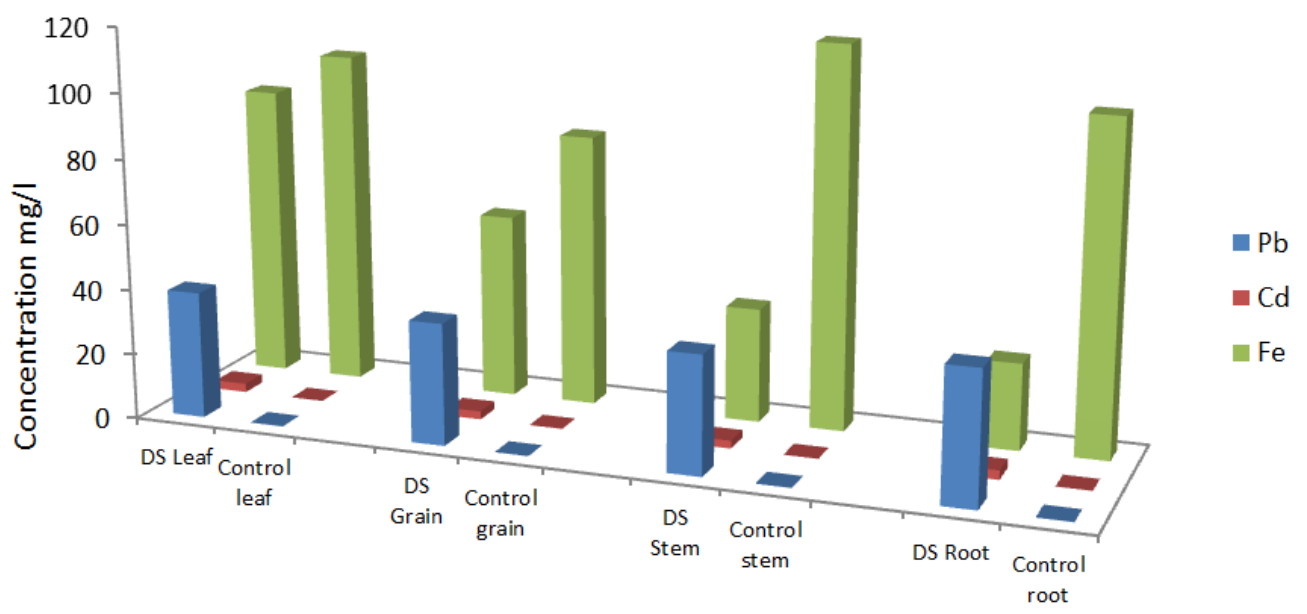

Maize parts

Key: Each bar represent maize parts; successive colors represents parts' heavy metal concentrations; DS = Dumpsite Area.

Figure 6. Lead, Cadmium and Iron in Cultivated Maize Parts and Control.

From the results obtained, the TF in all maize-parts was less than 1 for all the three heavy metals. However, the maize root had the highest $\mathrm{TF}\left(\mathrm{TF}_{\text {root }}>\mathrm{TF}_{\text {leaf }}>\mathrm{TF}_{\text {grain }}>\mathrm{TF}_{\text {stem }}\right)$ (Table 3; Figure 5). Only the PLI values for $\mathrm{Cd}$ was above one (1), which indicated that there was higher uptake and accumulation of $\mathrm{Cd}$ in the maize plant from the polluted soil of the garden around the waste dumpsite while $\mathrm{Pb}$ and $\mathrm{Fe}$ levels were at the baseline.

Plants have evolved detoxification mechanisms [45] and the efficiency of these processes might result in the tolerance of the natural heavy metals [46]. Cereals such as maize are known to be good accumulators of contaminants [26, 28]. Lead and cadmium are the most widespread no-nutrient heavy metals [29]. Results obtained in this study showed high concentrations of $\mathrm{Pb}, \mathrm{Cd}$ and $\mathrm{Fe}$ in the roots, stems, leaves and grains of the studied maize plants when compared with levels in the same parts in reference site samples. The concentration of $\mathrm{Pb}, \mathrm{Cd}$ and $\mathrm{Fe}$ found in the Ori-Ile maize grain was considerably high, but the $\mathrm{Pb}$ and $\mathrm{Cd}$ level in the Ori-Ile maize root was the highest. According to Goldsbrough et al [47], uptake of toxic metals in plants along with vital elements occurs primarily through the root system. This corroborates the results obtain from the maize root and further clarifies why the concentration found in the root of the Ori-Ile maize was significantly high.

The highest concentration of $\mathrm{Fe}$ was found in the Ori-Ile maize leaf. According to Aliu et al [28], maize leaf is an active site of photosynthetic activities and the primary location of food production. This explains why $\mathrm{Fe}$ concentration in the leaf area was high since Fe is essentially required for photosynthesis. Fe is an essential plant nutrient and it functions to accept, donate electrons as well as plays important roles in the electron-transport chains of photosynthesis and respiration [48]. However, $\mathrm{Fe}$ is toxic when it accumulates to high levels and can act catalytically via the Fenton reaction to generate hydroxyl radicals, which can damage lipids, proteins and DNA [48].

High levels of $\mathrm{Pb}, \mathrm{Cd}$ and $\mathrm{Fe}$ in Ori-Ile maize parts could only be attributed to contamination of the soil on which the maize plants were grown. Cunningham and Ow [49] stated that plants can thrive in soil contaminated to levels that are often orders of magnitude higher than the standard regulatory limits. Olusoga and Osibanjo [30] obtained similar $\mathrm{Pb}$ and $\mathrm{Cd}$ concentrations in their study on metals in plant species found at dumpsite at Olodo area $[\mathrm{Pb}(32.6-295.3 \mathrm{mg} \mathrm{Pb} / \mathrm{kg}$ dry weight), $\mathrm{Cd}$ (0.93-56.14 Cd/kg dry weight)] and those found 
in farmland $[\mathrm{Pb}(31.8-88.75 \mathrm{mg} \mathrm{Pb} / \mathrm{kg}$ dry weight), $\mathrm{Cd}(\mathrm{N}$. D.-29.40 $\mathrm{mg} \mathrm{Cd} / \mathrm{kg}$ dry weight)]. Their results showed that the concentrations exceeded normal range of $\mathrm{Pb}$ and $\mathrm{Cd}$ in plants, although, the range they reported fall within critical concentrations of these two metals in plants $[50,51,52]$. The results obtained in this study compares well with the results reported by Olusoga and Osibanjo [30] for $\mathrm{Cd}$ while $\mathrm{Pb}$ level in this study was slightly higher.

Heavy metals like $\mathrm{Pb}$ and $\mathrm{Cd}$ have been shown to affect plant growth and production in a multiple way especially by inhibiting a number of physiological processes in plants [28]. Wallace et al [53] and Barcelo et al [54] reported that $\mathrm{Pb}$ and $\mathrm{Cd}$ are among the heavy metals shown to cause disturbance in plant ion balance as well as in plants water balance. They further stated that this could eventually results in interference with protein metabolism through influencing nitrate and sulphate reduction $[55,56] . \mathrm{Pb}$ have also being said to inhibits chlorophyll synthesis by causing impaired uptake of essential elements by plants [57] and high $\mathrm{Pb}$ content could lead to reduced vascular tissues [58]. Therefore, the uptake of $\mathrm{Pb}$ by Ori Ile maize could be detrimental to the maize plant by hindering the uptake of the essential mineral element needed by the maize. Aliu et al [28] in their study on the exposure of maize seedlings to $\mathrm{Pb}, \mathrm{Cd}$ and $\mathrm{Hg}$ observed that the leaf area had the highest values of the heavy metals at a percentage value of $82.01 \%$. Although the result obtained in this study indicated that the root had the highest concentration for lead and cadmium, the concentration found in the leaf was also significantly high.

Malecka et al [59] indicated that $\mathrm{Pb}$ concentration in the exposed plant increased as the concentration in the soil increased. However, the results of this study affirmed maize as a significant accumulator for $\mathrm{Pb}, \mathrm{Cd}$ and $\mathrm{Fe}$. Results obtained in this study likewise showed that the concentrations of $\mathrm{Cd}$ is relatively low compared to concentrations of $\mathrm{Pb}$. Fe concentrations found was significantly less than the level of $\mathrm{Fe}$ in the reference site. According to Spectrum analytic [20], Fe toxicity is primarily $\mathrm{pH}$ related and its visible symptoms are likely to be a deficiency of other nutrient (s). The $\mathrm{pH}$ value obtained in soils of Ori-Ile dumpsite environment was acidic $(\mathrm{pH}<6)$ and it could be that the maize plants had easy access to the $\mathrm{Fe}$ and as such absorbed significant concentration from the soil.

\section{Conclusion}

Heavy metal accumulation in soils and plants is of increasing concern due to the potential human health risks $[28,60]$. This eventually often leads to food chain contamination which is one of the important pathways for the entry of these toxic pollutants into the human body [61, 62]. Therefore, according to Muchuweti et al [11], the extreme build-up of heavy metals in soils can lead to higher heavy metal uptake by plants, and this can affect the quality and safety of food. As a result, since the toxic heavy metals concentration in the most consumed part of the experimental maize are high, there is tendency of these metals being transferrred to both animals and humans that consume the contaminated maize parts regularly. This may result in several unpleasant health effects, if bio-accumulated. Thus, while the maize grown on the topsoil of the experimental garden have shown active phyto-extraction via the root as well as high bio-accumulative property, this study recommends that the maize grown in gardens within $25 \mathrm{~m}$ from the dumpsite is unfit for human and animal consumption. Such crops could expose the residents and their animals to undesired effects of heavy metal's toxicity. in view of this, the remediation of the polluted soils of Ori-Ile battery waste dumpsite and its surroundings is highly recommended.

\section{References}

[1] Adejumo, S. A., A. O. Togun, J. A. Adediran and M. B. Ogundiran, 2011. In-Situ Remediation of heavy metal contaminated soil using mexican sunflower (Tithonia diversifolia) and cassava waste composts. World J. Agric Sci., 7: 224-233.

[2] Oni, A. A., 2010. Physico-chemical parameters and toxicity of solid waste and leachates on selected animals at Aba-Eku landfill site, Ibadan, Nigeria. Ph. D. Thesis. Department of Zoology, University of Ibadan. 330p.

[3] Environmental Protection Agency (EPA), 1998. Guidelines for Ecological risk assessment. Washington, DC: Risk Assessment Forum, Environmental Protection Agency, pp. 9-1 to $9-66$. EPA/630/R-95/002F.

[4] Environmental Protection Agency (EPA), 2000. Wastewater technology sheet: chemical precipitation. United State Environmental Protection, EPA 832-F-00-018. Available on http://www.epa.Gov/own/ mtb/chemical_precipitation.pdf. Accessed 07/07/2010.

[5] Hussein, H., Farag, S., Kandil, K. and Moawad, H., 2005. Resistance and uptake of heavy metals by Pseudomonads. Process Biochem. 40: 955-961.

[6] Gardea-Torresdey, J., Peraltavidea, J., Delarosa, G. and Parsons, J., G., 2005. Phytoremediation of heavy metals and study of the metal coordination by X-ray absorption spectroscopy. Coordination Chemistry Reviews, 249 (17-18), 1797-1810.

[7] Kumar, D., Rai, J. and Gaur, J. P., 2012. Removal of metal ions by Phormidium bigranulatum (Cyanobacteria)-dominated mat in batch and continuous flow systems. Bioresour. Technol., 104 (2012), pp. 202-207.

[8] Shivhare L. and Sharma S (2012). Effects of toxic heavy metal contaminated soil on an ornamental plant Georgina wild (Dahlia). Environ Anal Toxicol 2.

[9] European Union, 2002. Heavy Metals in Wastes, European Commission on Environment

(http://ec.europa.eu/environment/waste/studies/pdf/heavy_met alsreport.pdf)

[10] Adegoke, J. A., Owoyokun, T. O., and Amore, I. O., 2009. "Open Land Dumping: An Analysis of Heavy Metals Concentration of an Old Lead-Battery Dumpsite". Pacific Journal of Science and Technology. 10(2):592-595. 
[11] Muchuweti, M., Birkett, J. W., Chinyanga, E., Zvauya, R., Scrimshaw, M. D. and Lister, J. N., 2006. Heavy metal content of vegetables irrigated with mixtures of wastewater and sewage sludge in Zimbabwe: implication for human health. Agri. Ecosys. Environ. 112, 41-48.

[12] Khan, S., Cao, Q., Zheng, Y. M., Huang, Y. Z., and Zhu, Y. G. 2007. Health risks of heavy metals in contaminated soils and food crops irrigated with wastewater in Beijing, China. Environ. Poll 6,1-7.

[13] Iyengar, V., Nair, P., 2000. Global outlook on nutrition and the environment: meeting the challenges of the next millennium. Science of the Total Environment 249, 331e346.

[14] Türkdogan, M. K., Fevzi, K., Kazim, K., Ilyas, T., Ismail, U., 2003. Heavy metals in soil, vegetables and fruits in the endemic upper gastrointestinal cancer region of Turkey. Environmental Toxicology and Pharmacology 13, 175e179.

[15] Rattan, R. K., Datta, S. P., Chhonkar, P. K., Suribabu, K. and Singh, A. K., (2005). Long-term impact of irrigation with sewage effluents on heavy metal content in soils, crops and groundwater: A case study. Agric. Ecosyst. Environ., 109: 310-322.

[16] Ioan, S., Cosma, C., Todică, M., Bolboacă, S. D., and Jäntschi, L., 2008. "Analysis of Soil Heavy Metal Pollution and Pattern in Central Transylvania”. Int. J. Mol. Sci. 9: 434-453.

[17] United States Department of Agriculture, (USDA), 2000. Heavy Metals Contamination, Soil Quality Urban Technical Note 3, Natural Resources Conservation Service.

[18] Fargasova, A., 2001. Phytotoxic Effects of $\mathrm{Cd}, \mathrm{Zn}, \mathrm{Pb}, \mathrm{Cu}$ and $\mathrm{Fe}$ on Sinapis alba L. seedlings and their accumulation in roots and shoots. Biol. Plantantarum, 44: 471-473.

[19] Geebelen, W., Vangronsveld, J., Adriano, D. C., Carleer, R. and Clijsters, H., 2002. amendment-induced immobilization of lead in a lead-spiked soil: evidence from phytotoxicity studies. Water Air Soil Pollut., 140: 261-277.

[20] Spectrum analytic Inc., 2013. Iron $(\mathrm{Fe}++)$. In: Agronomic Library. Available online at: http://www.spectrumanalytic.com/support/library/ff/Fe_Basic s.htm

[21] Oyediran, I. A. and Aladejana, J. A., 2011. Assessment of Impact and Safety Status of Remediation of Lead Contaminated Soil using Excavation Method: A Case Study of Olodo, Ibadan, Southwestern Nigeria. Proceedings of the Environmental Management Conference, Federal University of Agriculture, Abeokuta, Nigeria.

[22] Ononuga A. O., 2016. Heavy metals accumulation in soil, water, maize and chicken at ori-ile battery waste dumpsite, Olodo, Ibadan, Nigeria. Ph. D. Thesis. Department of Zoology, University of Ibadan. 17-18p.

[23] Obi IU (1991). Maize: Its agronomy, diseases, pests and food values. Optimal computer solutions limited, Enugu 208 p.

[24] Agbogidi O. M., Eruotor P. G., Akparobi S. O. and Nnaji G. U., 2007. Heavy Metal Contents of Maize (Zea mays L.) Grown in Soil Contaminated with Crude Oil. International Journal of Botany, 3: 385-389.

[25] Food and Agriculture Organization (FAO), 2002. The State of Food Insecurity in the World. Published in 2002 by the Food and Agriculture Organization of the United Nations, Viale delle Terme di Caracalla, 00100 Rome, Italy. (C) FAO 2002.
ISBN 92-5-104815-0.

[26] Malgorzata, H. and Andzej N., 2005. Monitoring of bioremediation of soil polluted with diesel fuel applying bioassays. Elect. J. Polish Agric. Univ., 8: 1-2.

[27] Malkowski, E., Kurtyka R. and Kita A., 2005. Accumulation of $\mathrm{Pb}$ and $\mathrm{Cd}$ and its effect on $\mathrm{Ca}$ distribution in maize seedlings (Zea mays L.). Polish J. Environ. Stud., 14: 203-207.

[28] Aliu, S., Gashi B., Rusinovci I., Fetahu S. and Vataj R., 2013. Effects of some heavy metals in some morpho-physiological parameters in maize seedlings. Am. J. Biochem. Biotechnol., 9: 27-33.

[29] Mihailovic, N., 2010. Growth and ion uptake in maize plants exposed to $\mathrm{Pb}, \mathrm{Cd}$ and $\mathrm{Ni}$ depend on $\mathrm{NO} 3 / \mathrm{NH} 4$ ratio. Botanica Serbica, 34: 15-20.

[30] Olusoga, T. O. and Osibanjo, O. O., 2007. Contamination of soil with battery wastes: prospect for phytoremediation. European Journal of Scientific Research 17.1: 6-10.

[31] GIS Konsult (Geography Information System), 2012. Map informations and Geographical Mapping. Opposite Awolowo Junction, Bodija, Ibadan.

[32] United States Environmental Protection Agency (USEPA), 2000. Data Quality Objectives Process for Hazardous Waste Site Investigations. EPA QA/G-4HW Final. Office of Environmental Information Washington, DC 20460.

[33] Adie, G. U. and Osibanjo, O., 2009. Assessment of SoilPollution by Slag from an Automobile Battery Manufacturing Plant in Nigeria. African Journal of Environmental Science and Technology 3 (9): 239-250.

[34] Jones, J. B. Jr., Wolf, B. and Mills, H. A., 1991. Plant Analysis Handbook. A Practical Sampling, Preparation, Analysis and Interpretation Guide. Micro-Macro Publishing, Athens, GA, pp 213-220.

[35] Agunbiade, F. O. and Fawale, A. T., 2009. Use of Siam Weed Biomarker in Assessing Heavy Metal Contamination in Traffic and Solid Waste Polluted Areas. International Journal of Environmental Science and Technology 6 (2): 267-276.

[36] Cui, Y. J., Zhu, Y. G., Zhai, R., Huang, Y., Qiu, Y., Liang, J., 2005. Exposure to metal mixtures and human health impacts in a contaminated area in Nanning, China. Environment International 31, 784e790.

[37] National Environmental Standards and Regulations Enforcement Agency. (NESREA), 2011. National Environmental (Surface and Groundwater quality) Regulations. S. I. 22.

[38] Chirenje, T., Ma, L., Reeves, M. and Szulczewski, M., 2004. Lead distribution in near-surface soils of two Florida cities: Gainesville and Miami. Geoderma 119: 113-120.

[39] World Health Organization, (WHO), 1989. Heavy metals environmental aspects. Environment Health Criteria. No. 85. Geneva, Switzerland.

[40] Kabata-Pendias A. and Pendias, H. K., 1984. Trace Elements in soils and Plants. $2^{\text {nd }}$ edition. CRC Press, Boca Raton Ann Arbor. $10-20 \mathrm{p}, 45-78 \mathrm{p}$.

[41] Atayese, M. O., A. I. Eigbadon, K. A. Oluwa and J. K. Adeosun, 2008. Heavy metal contamination of Amaranthus grown along major highways in Lagos, Nigeria. Afr. Crop Sci. J., 16: 225-235. 
[42] Onianwa, P. C. and Fakayode, S. O., 2000. Lead contamination of topsoil and vegetation in the vicinity of a battery factory in Nigeria. Environmental Geochemistry and Health 22.3: 211-218.

[43] World Health Organization, (WHO), 1992. Cadmium. International programme on chemical safety. Environmental Health criteria 134:13.

[44] Eddy, N. O., Odoemelem, S. A. and Mbaba, A., 2006 Elemental composition of soil in some dump sites. Journal of environmental, agricultural and food chemistry 5.3:1349-1365.

[45] Clemens, S., 2001. Molecular mechanisms of plant metal tolerance and homeostasis. Planta 212: 475-486.

[46] Salt, D. E., Blaylock, M., Nanda Kumar, P. B. A., Dushenkov, V., Ensley, B. D., Chet, I., and Raskin, I., (1995). "Phytoremediation: A Novel Strategy for the Removal of Toxic Metals from the Environment Using Plants." Biotechnology. Vol. 13, 468-474.

[47] Goldsbrough, P. and others, 1995. "Phytochelatins and Metallothioneins: Complementary Mechanisms for Metal Tolerance?" Abstract Book: Fourteenth Annual Symposium 1995 in Current Topics in Plant Biochemistry, Physiology and Molecular Biology. Pages 15-16.

[48] Connolly, E. L. and Guerinot, M. L., 2002. Iron Stress in Plants. Genome Biol. Vol. 3 (8). 1024.

[49] Cunningham, S. D. and Ow, D. W., 1996. Promises and prospects of phytoremediation. Plant Physiol. 110:715-719.

[50] Bowen, H., 1966. Trace elements in Biochemistry. Academic Press, London and New York.

[51] McLean, K., Robinson, A. and MacConnel, H. 1987. The effect of Sewage sludge on the heavy metal content of soils and tissues. Commun. In Soil Sci. Plant Anal. 1987; 18(11): 1303-1316.

[52] Holdgate, M., 1979. A perspective of environmental pollution. Cambridge University Press, Cambridge.

[53] Wallace, A., Wallace G. A. and Cha J. W., 1992. Some modifications in trace metal toxicities and deficiencies in plants resulting from interactions with other elements and chelating agents--the special case of iron. J. Plant Nutr., 15: $1589-1598$.
[54] Barcelo, J., C. Cabot and C. Poshenrieder, 1986. CadmiumInduced decrease of water stress resistance in bush bean plants (Phaseolus vulgaris L. cv. Contender) II. Effects of Cd on endogenous abscisic acid levels. J. Plant Physiol., 125: 27-34.

[55] Nussbaum, S., Schmutz D. and Brunold C., 1988. Regulation of assimilatory sulfate reduction by cadmium in Zea mays L. Plant Physiol., 88: 1407-1410.

[56] Hernandez, L. E., Garate A. and Carpena-Ruiz R., 1997. Effects of cadmium on the uptake, distribution and assimilation of nitrate in Pisum sativum. Plant Soil, 189: 97100 .

[57] Burzynski, M., 1987. Influence of lead and cadmium on the absorption and distribution of potassium, calcium, magnesium and iron in cucumber seedlings. Acta Physiol. Plantarum, 9: 229-238.

[58] Antosiewicz, D. M., 1992. Adaptation of plants to an environment polluted with heavy metals. Acta Soc. Botanicorum Poloniae, 61: 281-299.

[59] Malecka, A., Mensinger, A., Hanc, A., Danuta, B. and Tomaszewska, B., 2012. Antioxidative defense system in Pisum sativum roots exposed to heavy metals. Pol. J. Environ. Stud., 6: 1721-1730.

[60] Singh, B. P., Hatton, B. J., Singh, B., Cowie, A. L. and Kathuria, A. (2010). Influence of biochars on nitrous oxide emission and nitrogen leaching from two contrasting soils. Journal of Environmental Quality 39, 1-12.

[61] Khan, S., Cao, Q., Zheng, Y. M., Huang, Y. Z and Zhu, Y. G., 2008. Health risks of heavy metals in contaminated soils and food crops irrigated with wastewater in Beijing, China. Environmental Pollution 152: 686-692.

[62] Wilson, B., Pyatt, F. B., 2007. Heavy metal dispersion, persistence, and bioaccumulation around an ancient copper mine situated in Anglesey. UK. Ecotoxicology and Environmental Safety 66, 224e231.

[63] American Society for Testing and Materials (ASTM), 1995. Book of ASTM Standards. Vol. 04.08: Soil and Rock (I). N. C. Furcola, Ed., American Society for Testing and Materials, Philadephia, PA. 